\title{
ESCAPING THE IVORY TOWER: LEGAL RESEARCH ON HUMAN RIGHTS FROM A CRITICAL PERSPECTIVE ${ }^{1}$
}

\author{
DOLORES MORONDO TARAMUNDI²
}

\begin{abstract}
This article aims to address some of the criticisms that have been made of human rights research, especially of human rights research conducted by legal scholars. It argues that a conscious and critical approach to the limitations of the 'ivory tower' of legal scholarship on rights is becoming increasingly necessary in a research context marked by the convergence of multiple disciplines, the ever-growing contestation of human rights, and the complexity of the international regime for the protection of human rights. This article outlines three strategies that could be useful for legal scholars to escape from the ivory tower and make a significant contribution to multidisciplinary human rights studies.
\end{abstract}

Keywords: legal method, legal research, interdisciplinarity, intersectoriality, activism, critical theory, human rights theory

Contents: I.THE 'IVORY TOWER': CRITICISM OF THE LIMITS OF LEGAL SCHOLARSHIP ON HUMAN RIGHTS; I.1.Criticism of the lack of methodological rigour in a technical sense; I.2.Criticism of the lack of methodological rigour in a subjective sense; I.3.Separating the wheat from the chaff in the criticism of (the methodology used by) human rights legal research; II.THE NEW WORK CONTEXT FOR HUMAN RIGHTS LEGAL SCHOLARSHIP ; II.1.The contestation of human rights; II.2.The complexity of human rights law; III.THE ESCAPE ROUTES FROM THE IVORY TOWER: SOME CUES; III.1.Disclosure; III.2.Critique; III.3.Cowork/Network; IV.CONCLUSIONS

\section{THE 'IVORY TOWER': CRITICISM OF THE LIMITS OF LEGAL SCHOLARSHIP ON HUMAN RIGHTS}

A wave of concern about the existing methodological problems in human rights research began in Europe about a decade ago (Coomans et al., 2009 y 2010; McConnell and Smith, 2018). The methodological issue is not a new problem in human rights research. In fact, it could be said that it is a recurring problem rather than a new one, even though this has not been explicitly stated (Taekema and van Klink, 2011, p. 1). This is also true of other areas of legal research (or, more precisely, those originating from that field $\left.^{3}\right)$. In general, the debate on methodology in the legal field is closely linked to the debate on the very nature of legal research and to the ultimate question as to whether it

\footnotetext{
1 The research leading to this publication has received funding through the project "La desigualdad compleja en las sociedades plurales. Indicadores para las políticas públicas" (DER2016-77711-P) of the National I+D+i Plan of the Spanish Ministry of Economy.

${ }^{2}$ Human Rights Institute, University of Deusto, Spain (dolores.morondo@ deusto.es).

${ }^{3}$ In fact, as in other areas of legal scholarship, the discussion on human rights research methodology in legal academia does not revolve around the label of 'method' or 'methodology', but around the more general question of whether it is possible to obtain legal knowledge of a given topic, usually by discussing its normative meaning, definition, sources, etc. In this sense, the lively debate held in the journal Doxa (doxa.ua.es) in the 1980s and 1990s, and the discussion about Luigi Ferrajoli's theses on fundamental rights (Ferrajoli 2001) are examples of the discussion on human rights methodology.
} 
can be descriptive, or whether it is necessarily normative in nature, as are the materials it investigates (Smits, 2009, p.45).

From the mid-1990s onwards, human rights research has been a multidisciplinary field. It had previously been the exclusive remit of public international law, and therefore there had been no need to raise methodological issues or even consider the epistemological position to be adopted. The historical circumstances that had accompanied the birth of the Universal Declaration of Human Rights, the precarious balance of the political consensus, ${ }^{4}$ and the period of intense production of international treaties that began in the 1960s had led legal scholars to deal with the mechanisms for guaranteeing rights, ignoring theoretical and philosophical issues, as advocated by Bobbio in 1964 (Bobbio 1990, p. 16).

However, the increasingly multidisciplinary nature of this area of study has reopened a series of questions, starting with the methodological one. Important methodological shortcomings have been identified, particularly in connection with legal research on human rights, which is frequently considered to inhabit an ivory tower. The remainder of this section reviews the criticisms of human rights legal scholarship. In order to plan the escape from the ivory tower, firstly a discussion is provided of the new characteristics of the research context in which this methodological challenge is to be faced (section 2). Secondly, an escape route from the ivory tower is outlined that can serve as a basis for a much-needed methodological reflection (section 3).

\section{I.1. Criticism of the lack of methodological rigour in a technical sense}

Compared to research related to other social phenomena or produced by other scientific communities, the research conducted by human rights scholars has been often described as 'sloppy', which has the double meaning of careless and bungling, but also sentimental and emotional. In other words, human rights research, especially that carried out by legal scholars, has been accused of lacking methodological rigour from the technical and the subjective points of view.

From a technical point of view, it has been found that there has frequently been no reference to the method used in human rights research, and much less a discussion about the adequacy or the impact of a particular method in relation to other possible methods of analysis, or its appropriateness to the research question (Coomans et al., 2010, p. 181).

In the case of legal research, in particular, the method or methods that are not explicitly referred to are not even noticeable from the perspective of other social sciences. The legal method in general (not only in human rights research) is invisible to those outside legal academia, thus giving rise to the idea that legal research lacks a method. Methodology is also a non-reflective area or form of knowledge within legal research,

\footnotetext{
${ }^{4}$ This is summed up in a well-known sentence by Jacques Maritain: 'We agree on these rights, providing we are not asked why' (Maritain, 1983, p. 94).
} 
both in academic research and in legal practice, so legal scholars rarely know how to answer questions about their methods or their methodological training. In a short questionnaire conducted by Eva Brems about this issue, half of the people interviewed replied that they had never received methodological training but, above all, the same percentage responded that they did not feel the need to receive that type of training or discuss methods, unless they had to work in multidisciplinary groups or apply for research grants (which usually include a methodology section) (Brems, 2009, pp. 84-85). In other words, legal scholars who engage in legal research in human rights not only do not receive training on (legal?) research methods, but they do not feel the need for such training or to discuss the research method while they are among legal scholars. In fact, it is generally the interaction outside their scientific community that leads them to consider the methodological issue.

Not only do legal scholars seem baffled at the questions about their method, but they also do not seem concerned about the criticisms made of their work because of a lack of methodology. This may be partly due to the fact that social science tends to judge legal research according to whether or not it uses social research methods, and whether or not legal research pursues research objectives and questions that can be understood from within empirical social science research (Feldman, 1989, pp. 2-5). Legal scholarship has been frequently accused of not being concerned about the effectiveness of human rights (Coomans et al., 2010, p. 181), for example; or about whether legal provisions for human rights really defend human dignity or not (Kennedy, 2004, p.24); or about what could have been the 'true' reasons for a State to sign a certain human rights treaty. From outside the legal community, it is usually considered that only the part of legal research that is closest to the social sciences (socio-legal research or research by the various 'law \& something') is actual research. But most of legal research is doctrinal or dogmatic, ${ }^{5}$ and legal scholars who conduct it rarely feel challenged by that kind of criticism: their job is not to study the effectiveness of the norms, nor their political or economic appropriateness, but the effectiveness and validity of the norms within the legal system, which is a normative dimension of the rights rarely visible to the social sciences.

Finally, legal scholars' lack of reflectivity on the legal method and its invisibility from outside the legal community make it difficult to comprehensively convey a criticism of the methodology: what is missing, what is not done, and the standards to be used to assess the validity and the scientific nature of the method. There is a good example for this in the above-mentioned study conducted by Eva Brems. After examining a range of legal research papers on human rights published in some prestigious international journals, Brems concluded that explaining the method used was not the norm in these publications. She also explained what had counted as a "methodological description" in her review; she admitted that a single phrase along the lines of 'the research question will be addressed through the analysis of the jurisprudence of the European Court of Human Rights' was sufficient (Brems, 2009, pp. 87-88). Thus Brems' review shows not only how

\footnotetext{
${ }^{5}$ The discussion below will use the expressions 'legal doctrine', 'legal dogmatics' and 'doctrinal research' as synonyms. I am aware that there are differences between them. However, these would not be very relevant to the issues at stake here, and elaborating on these distinctions in an article of general scope would create an additional difficulty.
} 
often this legal research in human rights is conducted without any methodological indication, but also the lack of guidelines on what it is and should be considered as method, methodology and methodological discussion in legal research.

\section{I.2. Criticism of the lack of methodological rigour in a subjective sense}

In addition to this lack of technical rigour in the selection and application of the method, human rights research is also considered to have methodological shortcomings from a subjective point of view.

Some authors have attributed the lack of attention to research methodology to the fact that individuals who conduct research into human rights are often activists or were former activists (Føllesdal, 2009, p. 233; Coomans et al., 2010, p. 179). In these cases, methodology may be dispensed with because, if they ignore the demands and constraints involved in applying a rigorous methodological approach, scholars/activists can 'point' research towards the conclusions they previously established, a trap that leads to 'wishful thinking' (Coomans et al., 2010, p. 179); in other criticisms that used harsher language, human rights research has been considered to be 'ideological' in nature, as opposed to scientific. Andreas Føllesdal, for example, considers this research to be 'normative': ${ }^{6}$ as these researchers are activists, there is a tendency to 'dull an appropriately sceptical attitude' towards human rights institutions. Human rights research has an 'agenda' that seeks to promote human rights (or, in Føllesdal's words, the 'legal human rights' that national and international norms are, as opposed to the philosophical conceptions of human rights or philosophical rights, which relate to human dignity and/or social justice). This agenda causes the pronounced absence of internal criticism of human rights by human rights scholars. According to Coomans et al. (2010, p. 182), it is the 'passionate' belief held by these legal scholars/activists in the goodness and usefulness of human rights norms and institutions that leads them to direct their work towards improving and respecting human rights norms, ignoring that these are merely instruments in the defence of human dignity and that they may not even be good instruments.

In this sense, human rights research - and again, in particular, investigation conducted by legal scholars - is accused of being lenient or deferential towards human rights institutions; and of putting itself at the service of the establishment by being reluctant to make any unnecessary (or even necessary) criticism of the activities and output of international human rights organisations. The research carried out by these legal scholars/activists is therefore unable to promote transformation, and it cannot even properly defend human rights institutions or the implementation of human rights.

\footnotetext{
${ }^{6}$ Føllesdal makes a distinction between the 'normative' of human rights research and the 'normative' in political philosophy (his own disciplinary field). Legal research in human rights is 'normative' in a pejorative sense, since this 'normative' attitude is identified with the absence of the 'appropriate sceptical attitude' that should characterise scientific research, which borders on an also pejorative use of 'ideology'. The normative nature of philosophical research in human rights, however, seeks to examine the justifiability of norms and values (Føllesdal, 2009, p. 233).
} 
In summary, it has been argued that the human rights scientific community, especially legal scholars, live in and maintain an ivory tower of abstract human rights research. Their research has been portrayed as being far removed from real experiences and from the actual effectiveness of human rights to protect the dignity of millions of people who are abused, and as being unable to create the conditions for ensuring that their knowledge output is appropriate.

\section{I.3. Separating the wheat from the chaff in the criticism of (the methodology used by) human rights legal research}

The criticism of a lack of methodological rigour in human rights legal research related to both technical and subjective aspects is not unproblematic. However, I believe that both aspects are worthy of being taken into account to appreciate, and ultimately correct, the methodological limitations of human rights research.

In order to better focus on those aspects of legal research methodology that should be strengthened, it would be useful to separate the wheat from the chaff in terms of criticism. This highlights a number of issues.

First of all, it is striking that both the origin of these criticisms and the discomfort of legal scholars themselves when talking about methodology emerge in the context of the increasingly multidisciplinary nature of the field of human rights research. At least since the late 1990s, human rights have no longer been an object of study only for public international law. The interest that human rights have aroused in other disciplines enriches our knowledge about them, but radically changes the context of study. Human rights are a multidimensional phenomenon, so any monodisciplinary approaches (not only legal research) are insufficient to understand their complexity. In order to create new knowledge about human rights, we have to accept this new multidisciplinary landscape and provide the necessary interdisciplinary research conditions for fruitful collaborations to take place between different partial forms of knowledge. While the methodological issue is not the only aspect involved, it is one of the fundamental factors in establishing such collaboration.

Secondly, a consideration can be made on the trail of the criticism regarding the weight of legal doctrine and legal dogmatics in human rights legal research. Many of the critical views on the work of human rights legal scholars do not seem to have a clear understanding of what constitutes legal dogmatics and what its purpose is. ${ }^{7}$ Hence it is necessary to give some thought to the relationship between doctrinal and non-doctrinal

\footnotetext{
${ }^{7}$ Some of the criticisms really seem to be begging the question. For example, it is surprising that human rights legal scholars are considered 'deferential' towards Human Rights Courts and the monitoring bodies of human rights institutions because they regard their pronouncements as authoritative. The function of legal doctrine is precisely examining the norms within a legal system, and within that legal system, legislative texts and decisions by courts are authoritative, they set the boundaries of the legal order that legal doctrine assesses. Of course, one may be interested in other things (for example, in finding what the social impact of certain decisions of Human Rights Courts is), but legal doctrine cannot be deemed to be doing a bad job because it fails to answer a question that is outside its remit. If you cannot hammer a screw, the fault does not lie in the hammer.
} 
legal scholarship (as it happens in other areas of legal studies ${ }^{8}$ ). Also, it should be investigated how legal doctrine can be productive to the other sciences; how its research results can be 'translated' for those outside legal scholarship; and ultimately, how to find methodologically appropriate ways to validate dogmatics against different external parameters.

A third point of reflection - closely linked to the idea of the ivory tower - is that related to the limits legal doctrine has in doing 'criticism.' What can the role of criticism be in legal doctrine? How can critical concepts that go beyond identifying contradictions and gaps, interpretations or misconceptions be introduced, in order to propose mechanisms for resolution? Can a critical concept be introduced and rendered operational to apprehend complexity and design appropriate responses? Can legal doctrine accept a form of 'external criticism' that does not ignore the systemic nature of rules, the authoritative sources of interpretation, etc.? One which does not fall into 'wishful thinking', confusing the wishes, the claims, and the individual experience of injustice with rights? Can the concept of criticism of critical theories be introduced to examine power relations?

A final consideration worth making at this stage, forced by criticism, is that a relationship between scientific reflection and legal practice is necessary in - and almost constitutive of - legal research. In the field of human rights research, this relationship is not only established between legal scholars and legal practitioners (human rights lawyers, judges, experts sitting in human rights monitoring bodies), but also with human rights activists who may not be lawyers (in fact, very often they are not). Can methodological reflection help us do human rights legal research that is not reduced to being a mere 'crutch'for practitioners' work? Is there such thing as basic legal research and applied legal research, as in the hard sciences? What is the difference between theoretical legal knowledge about human rights, and legal knowledge of human rights that is derived from both legal and non-legal practice, and from activism?

\section{THE NEW WORK CONTEXT FOR HUMAN RIGHTS LEGAL SCHOLARSHIP}

None of the above-mentioned arguments and criticism of legal methodology are new, nor have they changed substantially within legal science. ${ }^{9}$ However, as mentioned before, in human rights studies (and certainly in other fields of study related to social justice) questions are being raised that oblige legal scholars to explicitly rethink the methodological problem and to address it in a new way.

Before concentrating on the two issues that I believe have radically altered the landscape of human rights studies since the 1990s, I want to emphasise the role that disciplinary multiplicity plays as a catalyst in the new context for the work of human rights legal scholars.

\footnotetext{
${ }^{8}$ For example, in international law and European law (van Gestel and Micklitz, 2011; van Gestel et al. 2012), in the history of law (Jensen, 2016), or in comparative law (Legrand, 2017).

${ }^{9}$ Suffice it to recall the work of J. von Kirchmann The worthlessness of jurisprudence as a body of knowledge (English translation) (Die Wertlosigkeit der Jurisprudenz als Wissenschaft, Darmstadt, 1848).
} 
If one accepts the fact that there is disciplinary plurality in the field of human rights studies, the issue of interdisciplinarity and the methodological challenge that it entails also needs to be taken seriously. If what we can and want to know about human rights is no longer limited to the knowledge and understanding of the international norms that establish them, the analysis of the texts in which they are contained and the operation of the international organisations that are responsible for monitoring their compliance by States, it follows that we will need to have some mechanisms to answer the various questions we may want to ask.

This is a key aspect in the new reflexion on research methodology on human rights (McConnell and Smith, 2018; Andreasen et al., 2017; Coomans et al., 2009) but one that is usually resolved by using juxtapositions.

In interdisciplinary research, or even in research conducted by multidisciplinary teams, it is very important to establish forms of 'translating' between the different disciplines and epistemological and theoretical approaches in the research design stage. This will minimise the danger of 'incommensurability' between languages and research findings depending on the different methods used. In interdisciplinary research, it is necessary to move forward with methodological approaches and methods that can act as 'chameleons' or as 'amphibians', adapting to different environments and their requirements.

This task is clearly not to be performed by legal scholars by themselves. The construction of an interdisciplinary approach that goes beyond the juxtaposition or the substitution of some types of knowledge by other (equally partial) types, which is not dissolved in dilettantism or in a 'know-it-all' approach, and seeks to find a shared solution to new, more complex, multidimensional knowledge gaps, is a task to be undertaken by the scientific community as a whole. This process would ultimately transform that knowledge and turn it into a social production. This interdisciplinary transformation obviously cannot be addressed here. ${ }^{10}$ But it is important to realise that this is a fundamental challenge in the methodological scenario of current human rights research. If legal scholars (and all other scholars) wish to participate in that scenario, they have to act convergently, stepping outside of their ivory towers.

\section{II.1. The contestation of human rights}

This section deals with two aspects that change significantly the contexts in which the methodological issue needs to be considered. These two aspects (the contestation of human rights and the complexity of the human rights law system) make it necessary to deal with the methodological issue not only explicitly, but also in a way that is different from previous waves of concern about methodology.

${ }^{10}$ See the contribution by Cristina de la Cruz in this same issue. 
The first aspect is that the concept of human rights has become increasingly and more frequently contested.

The 40 years that separated the Universal Declaration from the end of the Cold War saw the affirmation of human rights as a powerful mechanism of political legitimation and as a vehicle for claims from radically diverse groups. The context and conditions in which human rights doctrine became extended and established during what came to be called the 'age of rights' (Bobbio, 1990) cannot be discussed here. However, paradoxically, at the time when Bobbio coined this term, a process of contestation of human rights matured and raised new and old issues on several fronts. The old issues, that had not been resolved at the time of the Universal Declaration, delayed the drafting of the International Covenants and their entry into force, and meandered throughout the Cold War period. They included the opposition between political civil rights and economic, social and cultural rights, the nature of rights as a 'natural' limit to the State, and their international protection as a limit to the sovereignty of the State. Some new issues also resulted from the global geo-political conditions that arose in the late 1960s, the decolonisation process, the emergence of regional human rights protection systems, the fall of communist regimes in Europe, and the development of international civil society organisations.

Since the beginning of the new century, a theoretical reflection has also emerged on the 'human rights crisis' (Klabbers, 2002; Hoover, 2012; MorondoTaramundi 2014) and the urgent need to re-found their doctrine. The human rights crisis does not really involve a new set of claims that are sometimes divergent or even in opposition to human rights as they were reflected in international human rights law. This process of contestation is not in itself a negative development, nor does it in itself discredit the age of rights, although it denounces some of its critical points. If we understand human rights as a corpus of rules, the processes of change and transformation of the law are inherent to the very idea of social regulation.

The human rights crisis that has been theorised since the beginning of the century has other components. In his analysis of the crisis, A. Langlois opposes this critical literature (which he qualifies as an 'anathema to the promotional propaganda of human rights that we are accustomed to hearing' (Langlois, 2012, p. 559) to the naive rhetoric of the human rights movement that includes universalism, indivisibility, inalienability and a long list of new rights, treaties and mechanisms. It is important to note that what is described as naive rhetoric and promotional propaganda of human rights are not marginal details, but their main theoretical elements (universality, indivisibility and inalienability) and operational components (positivisation, internationalisation and provision of control and guarantee mechanisms). In addition, the theoretical contestation of human rights in recent years has not so much questioned the specific political consensus on which the expansion of human rights was based, ${ }^{11}$ but the idea of a political consensus detached

\footnotetext{
${ }^{11}$ Indeed, many aspects of the political consensus around the Universal Declaration of 1948 may be (and have started to be) criticised (Jensen, 2016).
} 
from the objective (or, at least strong and compelling) foundations of human rights (Klabbers 2002; MorondoTaramundi 2014).

This is also, therefore, a crisis about the meaning of human rights, which has become undermined as they have been instrumentalised into playing a role in legitimising power. This crisis is also a struggle - not for rights- but for the meaning attributed to the expression 'human rights', including its rhetorical use in a symbolic function, the emotional pseudo-definitions, and the continuous prescriptive re-definitions. I think that the main vector of 'rhetoric' in human rights is this crisis and not, as Coomans, Gründfel and Kamminga (2010, pp. 182-183) argue, the mere fact that there are activists doing research or that human rights scholars - generally- want to improve the implementation and enjoyment of human rights.

This is the context in which human rights legal scholars have to work today: a human rights legal system where political consensus has become eroded and a struggle around the definition of human rights that includes some of its fundamental elements (foundations, portfolio, guarantees and subjects). I believe that human rights today -and probably since the 1990s- have the characteristics of 'essentially contested concepts' (Gallie, 1956). Essentially contested concepts are those notions 'the proper use of which inevitably involves endless disputes about their proper uses on the part of their users' (Gallie, 1956: 169). These concepts involve a disagreement about the reasons for attributing a certain meaning to a particular linguistic expression. ${ }^{12}$ Gallie warned that the indeterminate nature of these types of concepts cannot be resolved by appealing to logic or linguistics. The plurality of meanings of the expression 'human rights' and the mechanisms for determining the dominant meanings are not related to either coherence or semantic or pragmatic correction (as in the case of ambiguous expressions or vague concepts), but to more complex theoretical debates about their role in society and their fundamental properties.

\section{II.2. The complexity of human rights law}

A key aspect in the consideration that human rights legal scholars live in an ivory tower disconnected from reality is probably the way in which legal scholarship deals with the peculiarities of the international system for the protection of human rights.

From outside the legal community it is difficult to understand that legal scholars discuss whether a certain right exists without taking into account that in reality it is constantly violated by the authorities of a country or by private groups tolerated by the authorities of a given country; and that their victims have no protection from the law, and they are even often stigmatised and persecuted by law enforcement agencies and the judicial system. Likewise, it can be shocking that the existence of a certain human right that is claimed as such by millions of people can be denied, and that certain injustices

\footnotetext{
${ }^{12}$ It is my understanding that the category of an 'essentially contested concept' is also preferable to the concept/conception distinction made by R. Dworkin (1977, pp. 134-136), because it compels us to consider the problem from an argumentative/justifying point of view that is, in my opinion, more fruitful than the analytical-conceptual framework of Dworkin's distinction.
} 
cannot be categorised as human rights violations (Christiansen and Jensen, 2019; Alston, 2015).

It might seem that the human rights of legal scholars exist in a separate world, parallel to real life on the planet. And yet, the boundaries of that separate world are precisely the second aspect that changes the work context in which human rights legal scholars have to face their new methodological challenges. Burdened with the theoretical requirements of the doctrine of the universality, indivisibility and inalienability of human rights, human rights legal scholars have to enter a 'legal system' of a sui generis nature. Indeed, international human rights law has two sets of characteristics that alter the usual environments of legal theorisation (i.e. national legal systems) and that, by comparison, make it look like a 'crowded house' (Cruz Villalón, 2012). Cruz Villalón, Advocate General at the Court of Justice of the European Union, uses this analogy of the 'crowded house' to refer to the current state of fundamental rights in Europe ${ }^{13}$ in reference to both the rights that are considered fundamental, and to the people who deal with the complex task of declaring and applying them. While the intervention of Cruz Villalón highlighted how the judges of Constitutional Courts and Courts of Human Rights in Europe find it awkward to cohabitate in a crowded house, following this metaphor, I would like to discuss the difficulties that living in a crowded house entails for anyone who has to tidy up, find the belongings of each person in the house, and plan the shifts to watch TV there (i.e. legal scholars).

That is, one dimension of the complexity of the human rights protection system to which the legal scholarship has paid increasing attention (Brems, 2014; O'Cinneide, 2009; Brems and Ouald Chaib, 2018; Bribosia and Rorive, 2018) - is its multi-level and multi-layered nature. In general terms, it cannot be said what a certain human right consists of (what it protects, what cases it covers, what its limits are, and who its right holders and duty bearers are). In different places, human rights are defined by the interaction of up to four levels of protection ${ }^{14}$ that could be aligned with, contradict, or complement each other. Even where the founding provisions contain similar or identical formulations, there is a plethora of implementers of those standards that may differ in their interpretations or find themselves in so-called 'zones of friction'. Many of these zones of friction are jurisdiction problems or issues involving the application of legal concepts that the legal scholarship is called to examine and possibly solve.

The other dimension of the complexity of human rights law is the multitude of rights; not so much because there are too many human rights ${ }^{15}$ but, as Cruz Villalón pointed out, because their sources are broad and heterogeneous (national constitutions,

\footnotetext{
${ }^{13}$ Although Cruz Villalón applied the analogy in a more restricted way to the European protection system, I believe that, mutatis mutandis, it is even more valid when applied at a global level.

${ }^{14}$ International/global, supranational/regional, national and sub-state/local. See, for example (Marx et al., 2015).

15 The first decade of this century has produced vast literature around the 'inflation' of human rights, and the need to limit the rhetoric of their language and 'streamline' protection only for those rights that are most necessary in the defence of human dignity. I have examined some critical points of these doctrines in Morondo Taramundi (2014).
} 
supranational declarations, charters of rights, international treaties). There are major differences between human rights sources according to their origin, age, acquired authority, symbolic function, legal force and guarantees (Cruz Villalón 2012, p. 3). For all these reasons, the legal dimension of human rights cannot be fully understood by applying a view of the legal norms that is indebted to national legal systems. ${ }^{16}$ Not only does the corpus of human rights law have a significant proportion of international law; it also receives a different impact according to the various sources across a broad spectrum of graded rules. These sources are not interchangeable, although the formulation of the right they contain may be; but they are not incompatible either.

Therefore, it is for legal scholarship to elucidate the issues concerning to what extent human rights (which are configured in the interaction of multiple heterogeneous sources and in the practices of creation, interpretation and application of various subjects called upon for their protection) are legal in nature. These two dimensions, the multilayered character and the heterogeneity of the sources (including those that do not have full legal nature or are 'quasi-legal', 'soft law', etc.), have to be taken into account when thinking of human rights legal research as being necessarily different from the legal scholarship (doctrinal and non-doctrinal) that can be produced within national legal systems.

\section{THE ESCAPE ROUTES FROM THE IVORY TOWER: SOME CUES}

Let us assume, then, that we take seriously (albeit critically) the criticism of the methodological limitations that can be seen in human rights legal research today; and that, at the same time, we take into account this new multidisciplinary human rights research context, which has been shaken by the contestation of human rights and is extremely complex from a legal and regulatory point of view. This section outlines three issues; three escape routes from the ivory tower that could provide the basis for a methodological reflection on legal research in the new context. This endeavour commands a critical perspective that can contribute to the shared tasks involved in human rights studies and, at the same time, influence the real (although not immediate) protection of human rights and their values.

The proposals provided below are not fully developed strategies; they are not an instruction manual and they are not accompanied by a series of methods (with lowercase ' $m$ '). Nor are they alternative strategies to choose from. They are different elements for reflection on methodology (with a capital 'M'). Specifically, on the questions that need to be asked and answered when designing the research study, to be used as guidance in selecting specific methods; in recognising the limits of our research; in identifying complementarities in other scientific disciplines and with other sources of knowledge based on practice; and in assessing the possible social impact and the potential of knowledge for social transformation.

\footnotetext{
${ }^{16}$ Neither Kelsen's inverted pyramid, nor even Hart's rule of recognition seem adequate ways of thinking about these complex systems any longer (Smits, 2009, p. 55).
} 


\section{III.1. Disclosure}

The first escape route from the ivory tower involves engaging in methodological reflection and disclosing it. A conscious reflection on Methodology that is not merely the choice of a method to collect or to analyse data; it compels us (legal scholars) to position ourselves in the theoretical and epistemological panorama of scientific research and human rights studies.

This is undoubtedly easier in the field of non-doctrinal legal research, in the various sub-disciplines of law \& something and in law-in-context studies. In these areas, legal research can avail itself of the theoretical and methodological reflections of the disciplines that law is related to. But the fact that there is a well-trodden path does not mean that there are no further steps to take. The methodological reflection of multidisciplinary approaches in legal research should always adopt a self-analytical attitude to avoid a gradual movement away from the practice of law that may render it irrelevant to the understanding and transformation of law. In a review of the US debate on legal scholarship and methodology, van Gestel and Micklitz (2011) showed a fracture between two sides: 'multidisciplinarians' and 'doctrinalists.' Although multidisciplinarians take the credit and the intellectual reputation in elite universities, legal doctrine is still the foundation of legal education. In addition, their analysis showed that there are signs of a trend reversal in terms of considering 'black letter law' scholarship to be dead. This and other studies warn of the danger that the increasing instrumentalisation of law may reduce legal research to a mere policy instrument (van Gestel et al., 2012, p. 20).

This explicit reflection on the theoretical and methodological positions is even a greater challenge in the investigation of legal doctrine or legal dogmatics. In fact, many authors who have addressed the problem have opted to abandon legal doctrine in favour of multidisciplinary approaches in the study of law. This is not the position endorsed here. There is no reason to believe that if legal scholars engaged in discussions about objects other than rules, such as human dignity or democracy (as some do), their work would be of a higher methodological standard than their production as legal scholars. Much to the contrary. Nor is there any reason to believe that legal scholarship would be of better quality if it adopted methods from other disciplines, such as empirical research methods. ${ }^{17}$ Therefore, let legal scholars do their job. The escape route from the ivory tower does not require that legal doctrine or dogmatics disappear. The need for engaging in and disclosing methodological reflection does not mean that doctrine has no role in the new context of human rights research, or that legal scholars have to improvise or become recycled into something else (sociologists of law, or experts in legal anthropology or legal-social psychology).

Taking criticism and the new context seriously implies that legal doctrine can improve. A legal dogmatics of human rights can surely go beyond merely commentating

\footnotetext{
${ }^{17}$ Empirical legal research has grown significantly (van Dijck et al., 2018). However, critical voices have also emerged about its limits in terms of its production of knowledge about law (Leeuw, 2015).
} 
on and glossing judgments and new rules; it can contribute more than by simply uncritically systematising normative data and the techniques used to resolve contradictions or indeterminacies in the system. The methodological turn in the legal doctrine would also oblige legal scholars to learn to 'translate' and share our knowledge with other disciplines; to learn to incorporate the knowledge produced by other disciplines; and to understand the ways of 'leveraging' legal research outputs into wider and more complex environments than the relatively homogeneous communities of their legal scholar colleagues. Improving legal doctrine does not mean making it more similar to 'multi-disciplines' (the various 'law \& something' or law-in-context disciplines), but to refine its own nature.

\section{III.2. Critique}

A second escape route from the ivory tower is to make legal research more aware of the relationship between the human rights rules that are analysed and the power they contain and represent.

According to the traditional understanding of doctrine, legal scholars criticise the 'failures' of the legal system (contradictions, gaps, the indeterminacy of law) and propose solutions for the self-integration of the system. In other words, criticism means detecting errors and proposing solutions, but within the legal system, ${ }^{18}$ in order to improve the functioning of law.

In my opinion, criticism can have two additional meanings, both of which can have a place in human rights legal research, including the legal doctrine of human rights.

On the one hand, criticism can refer not simply to the detection of 'errors', but to the analysis of complexity. A critical study of legal doctrine, in this sense, would not only be devoted to identifying contradictions and proposing solutions de lege ferenda for the (better) protection or legal guarantee of a right, but would examine the 'errors' (contradictions, gaps or indeterminacies) found in relation to differentiated factors, both internal and external to the human rights law system. In this area, the law can be deemed to be a 'discipline in transition', to use the expression of the Dutch Evaluation Agency (in van Gestel et al., 2011, p. 2). It is a discipline that is facing a move towards more internationalised and globalised studies, towards reducing the predominance of legal practice within its purpose, towards multidisciplinarity and interdisciplinarity, and towards abandoning implicit traditions in favour of methodological approaches. Indeed, the approaches that have tried to deal with the idea of criticism as an understanding of complexity are numerous: for example, studies of the multi-layered nature of human rights protection mentioned earlier, work on distinction between substantive and procedural violations of human rights (Gerards and Brems, 2017), and the growing attention given to dissenting opinions (White and Boussiakou, 2009).

18 Obviously, this idea of a closed, comprehensive system, capable of self-integration (which is a requirement for the guiding value of modern legal science, that is, the certainty of the law) has been criticised as a 'myth' since the end of the nineteenth century by all anti-formalist currents of law (Calvo, 1994; van Gestel and Micklitz, 2011). 
There is a further meaning of 'criticism', which is in my opinion the one that most lends itself as a route of escape from the ivory tower. I refer to the use of 'critical' in the expression 'critical theory', that is to say, those theories that enquire about essential nodes of social power relations (based on class, gender, race, disability, migrant status and other fundamental axes of subordination of groups of individuals in our societies). In the study of human rights, critical theories are the perspective that would make it possible to understand human rights, according to the Bobbian adage of human rights as a result of new struggles against old powers. ${ }^{19}$ The question of power is, therefore, a fundamental issue in human rights research.

The investigation of power is always complicated, both because of the heterogeneous ways in which it manifests itself and because of its ability to become invisible, in particular, in contact with the law (which shows its institutionalised or 'naturalised'forms). It is important to reflect on how to deal with the issue of power in legal research and, in particular, in the legal doctrine of human rights.

This is an even more urgent question if we take into account the current context of contestation of human rights. So far the issue of power has been almost exclusively approached by those who review human rights law from critical perspectives, namely, those who carry out an examination of the law from outside the law. ${ }^{20}$ The approach to the issue of power from within is hindered today by the hegemonic theory of human rights law: the so-called theory of generations of human rights. The theory of the generations of human rights is a narrative about rights that was imposed during the Cold War and became both the historiography and the dominant theory of human rights. Proposed by Karel Vasak in 1979, the theory classifies human rights into three separate groups: firstgeneration human rights, which includes civil and political rights; second-generation human rights, which comprises economic, social and cultural rights, and third-generation human rights, made up of collective or solidarity rights. Each of the groups is explained on the basis of a different historical origin (the liberal revolutions, the democratisation processes and the proletarian movement of the nineteenth century, and the development processes linked to the post-colonial period, respectively). It is not just a historiography, since generations also function as analytical categories that explain the legal characteristics of each type of right: its legal nature, its right-holders and duty-bearers, and the type of associated guarantees. I agree with other authors (Jensen, 2017) that this is a fundamentally flawed theory (which actually concealed and sustained the ideological partition of the world in the Cold War). ${ }^{21}$ The theory of generations is an erroneous historiography of human rights (Jensen, 2017) and has no explanatory capacity from a legal point of view (Ferrajoli, 2011; Macklem, 2015). As a theoretical configuration, it

\footnotetext{
19"Human rights however fundamental are historical rights and therefore arise from specific conditions characterized by the embattled defence of new freedoms against old powers" (Bobbio, 1990, pp. XIII).

${ }^{20}$ The literature is too broad to be cited: feminist, anti-racist, post-colonialist and de-colonialist perspectives, Critical Legal Studies and post-Marxist perspectives, to mention only the best known.

${ }^{21}$ Jensen noted how Vasak's initial work in 1977 was intended to promote the agenda of a third generation of rights to development, peace and a healthy environment (although its implementation was of little benefit to the effective development of these rights, since the duty-bearers were not even defined for the thirdgeneration rights).
} 
also locks the definition of human rights to a series of historical 'roots' in a kind of genealogical determinism and establishes a strong hierarchy between them. It is essential to question it in order to appreciate the contestation of the definition of human rights by what is really a political phenomenon.

By contesting the theory of generations, a discussion can be initiated about power in human rights rules. It must be borne in mind, however, that both the genesis of the Declaration and the prominence of the theory of generations have effectively hindered the development of theoretical knowledge of human rights, and that we are at a very early stage in this regard. If one asks people (not students, but scholars) or reviews scientific works and manifestos of international organisations about what human rights are, the outcome is discouraging. Colleagues and reference works do what children do when they are learning to speak: finger-pointing. Definitions of human rights are in most cases denotative definitions (provided by enumeration or by giving examples) and even ostensive definitions (by directly pointing the finger at the Declaration or some other treaty). Any attempt beyond that falls into the circular definition: 'human rights are rights that are inherent to human beings.'

While the questioning of the so-called theory of generations and a renewed historiography of human rights (Jensen, 2016) suggested using new approaches to their definition and analysis, critical theories can and should play an important role in this development in order to preserve the ability to analyse human rights as an expression of power relations. Following the insights of other legal disciplines, when developing our theoretical and methodological assumptions about studying human rights law we must take into account that legal positivism (and the legal doctrine that is developed within that framework) prioritises the certainty of the law at the expense of excluding the challenges involved. Pierre Legrand warned that in the positive doctrines 'certain knowledge is banished from the sphere of significance, and some issues are made never to arise, therefore allowing for (...) an ultimately immaculate development of internal heuristic processes generating ultimately immaculate legal results' (Legrand, 2017, pp. 6-7). To avoid the epistemic self-referential and self-contained ivory tower, human rights legal scholars, as comparative law scholars, need to free themselves from the obsession with the certainty of law in legal positivism and recognise 'the essential unruliness of legal texts and legal cultures' (Legrand, 2017, p.44) also - or particularly so - in the human rights law systems.

\section{III.3. Co-work/Network}

The third escape route from the ivory tower is related to the 'crowded house' discussed in the previous section. The production of knowledge about human rights is a collective task in the hands of a heterogeneous plurality of subjects, who provide partial and sometimes fragmentary forms of knowledge.

This leads us, again, to the need to consider the methodological characteristics of this multidisciplinary and multisectoral type of research; one partaken of by subjects whose interest in research is not the production of knowledge in itself, nor its 
transmission, as in the case of scientific research, but its showcasing for practical purposes of social transformation or the defence of individual or collective interests.

I disagree with the argument posed by Coomans et al. (2009 and 2010) that the root of the problem regarding the quality of human rights research is the confluence between academia and activism (whether in terms of individuals or work teams), or that activism has an agenda and practitioners have a function. This would be like holding that, for medical research to be good, it has to be indifferent to the ability of the results to effectively cure diseases. As Feldman argued, scientific knowledge for all fields 'involves curiosity about the world, which may be stimulated either by the need to achieve a goal or by desire to understand something for its own sake' (1989, pp. 502-503). But Coomans and his colleagues were right in proposing the use of methodology, or rather, of methodological rigour and the critical function, as instruments to curb 'hagiography' and rhetorical uses in the field of human rights (which are frequent in some areas more than others, although not only found among activists).

A reflection on methodology can draw the areas of collaboration and the boundaries between human rights legal scholars and other actors who do research, but not scholarship, in the field of human rights. These lines would have the function of preserving the scientific aspirations of human rights legal scholarship, preventing its role from being reduced to being merely an ancillary instrument in the work of legal practitioners, human rights NGOs and policy-makers. Legal scholarship, in this way, can aspire not only to create more knowledge about the legal dimension of human rights, but also better knowledge, enhanced methods to approach that dimension, more accomplished theories to explain it, and better paradigms to integrate such knowledge with that of other disciplines.

The confluence of academia and activists also has zones of friction, even when working on a common theoretical approach. One of the greatest difficulties we face in our doctoral programme, for example, is that we receive applications for admission from people who have been working in the field for years (with national and international organisations in humanitarian intervention, in human rights policy implementation programmes, etc.). It is challenging to explain the difference (as an intellectual activity and as a result) between the doctoral thesis and a report (however detailed and innovative). It is difficult both for those who need to explain it and for those who seek to understand the explanation. At a time when scholars are required to produce research at an increasingly fast pace, to direct it more towards measurable impacts, to bring it closer to the interests (or the needs) of public administrations, and ultimately increasingly closer to transfer than to basic research, it is problematic to define what it means to 'push the boundaries of knowledge', and what the degree of ambition should be in a doctoral project. 


\section{CONCLUSIONS}

This paper has reviewed some of the most common criticisms of the research conducted by human rights legal scholars in relation to some of its methodological deficits. According to critics, these deficits are based on poor, self-referential research results that are detached from the reality of human rights in people's lives, and lacking in terms of critical capacity. In order to escape from the ivory tower of human rights legal research, however, some new characteristics of the context must be taken into account. The field of human rights studies nowadays has a plurality of scientific disciplines; human rights are a contested concept (unlike what happened until the end of the twentieth century); and human rights law, which has developed spectacularly, has extremely complex characteristics related to the sources of law, degrees of regulation, interpretation mechanisms and guarantee systems. Taking into account both the criticism and the new context, three 'escape routes from the ivory tower' have been outlined that suggest some elements to initiate a methodological reflection in human rights legal research. First, the need to disclose the actual methodological reflection, to ensure that it enters the very process of exposure to criticism and can eventually improve, as typically found in scientific work; and also to be able to 'translate' legal research for the other disciplines with which we have to collaborate in the 'crowded house' of human rights. Second, the need to incorporate criticism, not only as a review of the system's malfunctions -as traditionally has been done in legal doctrine- but with a view to studying the complexity of the power relations reflected in the norms. If human rights are born in the 'struggles in defence of new freedoms against old powers', power relations need to be accounted for. And third, the need for academics, practitioners and activists to collaborate and use methodological reflection accurately, so as to delimit the forms and confines of that collaboration, preserving the function of each group and the scientific ambition of legal scholarship.

\section{REFERENCES}

Alston, Ph. (2015) Report of the Special Rapporteur on extreme poverty and human rights A/HRC/29/31, Human Rights Council, 29th Session, 27 May 2015. Available at http://ap.ohchr.org/documents/dpage_e.aspx?si=A/HRC/29/31

Andreassen, B., Sano, H.-O., McInerney-Lankford, S. (2017) Research Methods in Human Rights. A Handbook. Cheltenham: Edward Elgar Publishing. https://doi.org/10.4337/9781785367793

Bobbio, N. (1990) L'età dei diritti. Torino: Einaudi.

Brems, E. (2014) 'Should Pluriform Human Rights Become One? Exploring the Benefits of Human Rights Integration', European Journal of Human Rights, 4, pp. 447470 . 
Brems, E. (2009) 'Methods in Legal Human Rights Research' in Coomans, F., Grünfeld, F. and Kamminga M.T. (eds.) Methods of Human Rights Research. Antwerp: Intersentia, pp. 77-90.

Brems, E. and Ouald Chaib, S. (2018) Fragmentation and Integrationin Human Rights Law: Users' Perspectives. Cheltenham: Edward Elgar Publishing. https://doi.org/10.4337/9781788113922

Bribosia, E. and Rorive, I. (2018) Human Rights Tectonics. Global Dynamics of Integration and Fragmentation. Cambridge: Intersentia https://doi.org/10.1017/9781780688060

Calvo García, M. (1994) Los fundamentos del método jurídico: una revisión crítica. Madrid: Tecnos

Christiansen, C. O. and Jensen, S. L. B. (eds.) (2019) Histories of Global Inequality. Basingstoke: Palgrave Macmillan.

Coomans, F., Grünfeld, F. and Kamminga M.T. (2010) 'Methods of Human Rights Research: A Primer', Human Rights Quarterly, 32, pp. 180-187 https://doi.org/10.1007/978-3-030-19163-4_1

Coomans, F., Grünfeld, F. and Kamminga M.T. (eds.) (2009) Methods of Human Rights Research. Antwerp: Intersentia

Cruz Villalón, P. (2012) Rights in Europe - The Crowded House, King's College London Working Paper in European Law 01/2012. Available at https://www.kcl.ac.uk/law/research/centres/european/research/CELWPEL01201 2FINAL.pdf

Dworkin, R. (1977) Taking Rights Seriously. Cambridge (Mass.): Harvard University Press

Feldman, D. (1989) 'The nature of legal scholarship', Modern LawReview, 52(4), pp. 498-517. https://doi.org/10.1111/j.1468-2230.1989.tb02611.x

Ferrajoli, L. (2001) Diritti fondamentali. Un dibattito teorico. Roma-Bari: Laterza

Follesdal, A. (2009) 'Methods of Philosophical Research on Human Rights' in Coomans, F., Grünfeld, F. and Kamminga M.T. (eds.) Methods of Human Rights Research. Antwerp: Intersentia, pp. 233-246

Gallie, W. B. (1956) 'Essentially Contested Concepts', Proceedings of the Aristotelian Society, 56 (1955 - 1956), pp. 167-198 https://doi.org/10.1093/aristotelian/56.1.167 
Gerards, J. and Brems, E. (2017) Procedural Review in European Fundamental Rights Cases. Cambridge: Cambridge University Press

Hoover, J. (2012) 'Human Rights Contested', Journal of Intervention and Statebuilding, 6(2), pp.233-246. https://doi.org/10.1080/17502977.2012.672692

Jensen, S. L. B. (2017) 'Putting to rest the Three Generations Theory of human rights' Open Global Rights, 15 November. Available at: https://www.openglobalrights.org/putting-to-rest-the-three-generations-theoryof-human-rights/

Jensen, S. L. B. (2016) The Making of International Human Rights: The 1960s, Decolonization and theReconstruction of Global Values. Cambridge: Cambridge University Press. https://doi.org/10.1017/CBO9781316282571

Kennedy, D. (2005) The Dark Side of Virtue: Reassessing International Humanitarianism. Princeton: PrincetonUniversity Press https://doi.org/10.1515/9781400840731

Klabbers, J. (2002) 'Glorified Esperanto? Rethinking Human Rights', Finnish Yearbook of International Law, 13, pp. 63-77

Langlois, A. (2012) 'Human Rights in Crisis? A Critical Polemic Against Polemical Critics', Journal of Human Rights, 11(4), pp. 558-570

https://doi.org/10.1080/14754835.2012.702473

Leeuw, F. L. (2015) 'Empirical Legal Research: The Gap between Facts and Values and Legal Academic Training', Utrecht Law Review, 11(2), pp. 18-33 https://doi.org/10.18352/ulr.315

Legrand, P. (2017) 'Jameses at Play: A Tractation on the Comparison of Laws', The American Journal of Comparative Law, 65(suppl. 1), pp. 1-136 https://doi.org/10.1093/ajcl/avx018

Macklem, P. (2015) The Sovereignty of Human Rights. Oxford - New York: Oxford University Press

Maritain, J. (1983) El hombre y el Estado. Madrid: Encuentro

Marx, A., Hachez, N., Meuwissen, K., Schmitt, P., Raube, K., Jaraczewski, J., Roszak, J., Lewis, T., Starl, K., MorondoTaramundi, D., Tuovinen, A.-K., and Weatherburn, A. (2015) 'Localizing Fundamental Rights in the European Union: What is the Role of Local and Regional Authorities, and How to Strengthen It?'Journal of Human Rights Practice, 7(2), pp. 246-271

https://doi.org/10.1093/jhuman/huv004 
McConnell, L. and Smith, R. (2018) Research Methods in Human Rights. London and New York: Routledge. https://doi.org/10.4324/9781315672632

Morondo Taramundi, D. (2014) 'Anti-retórica y minimalismo de los derechos humanos' in Fernández García, E. and Martínez García, J. I. (dirs.), Los derechos en el contexto ético, político y jurídico. Valencia: Tirant Lo Blanch, pp. 121-147

O'Cinneide, C. (2009) Human Rights and within Multi-layered Systems of Constitutional Governance: Rights Cosmopolitanism and Domestic Particularism in Tension. University College Dublin Law Research Paper 12/2009. Available at https://ssrn.com/abstract $=1370264$

Smits, J. (2009) 'Redefining Normative Legal Science: Towards an Argumentative Discipline' in Coomans, F., Grünfeld, F. and KammingaM.T. (eds.) Methods of Human Rights Research. Antwerp: Intersentia, pp. 45-57

Taekema, S. and van Klink, B. (2011) 'Editorial. Legal Methods under Discussion'. Recht en Methode, 1(1), pp. 11-12 https://doi.org/10.5553/ReM/221225082011001001002

Van Dijck, G., Sverdlov, S. and Buck, G. (2018) 'Empirical Legal Research in Europe: Prevalence, Obstacles, and Interventions', Erasmus LawReview 2 [online]. Available at http://www.erasmuslawreview.nl/tijdschrift/ELR/2018/2/ELR-D17-00020.pdf (accessed: 15 July 2019)

Van Gestel, R., Micklitz, H.-W. (2011) Revitalizing Doctrinal Legal Research in Europe: What about Methodology? EUI Working Papers LAW No. 2011/05. Available at https://cadmus.eui.eu/handle/1814/16825

Van Gestel, R., Micklitz, H.-W., Maduro, M. P. (2012) Methodology in the New Legal World. EUI Working Papers LAW No. 2012/13. Available at https://ssrn.com/abstract=2069872

White, R.C.A., and Boussiakou, I. (2009) 'Separate opinions in the European Court of Human Rights', Human Rights Law Review, 9(1), pp. 37-60

https://doi.org/10.1093/hrlr/ngn033

Received: August $19^{\text {th }} 2019$

Accepted: September $25^{\text {nd }} 2019$ 